Journal Wetenskap Health

\title{
Analysis of Determinant Factors in Stunting Children in Palopo, Indonesia
}

\author{
Resty Ryadinency ${ }^{1}$, Suwandi $N^{1}$, Try Ayu Patmawati ${ }^{1}$ \\ *Corresponding: resty.gizi@gmail.com \\ ${ }^{1}$ Mega Buana Palopo University, Indonesia
}

\begin{abstract}
Stunting is a global problem, especially in Indonesia. The prevalence of stunting among children under five in Palopo city is quite high, namely $36.0 \%$. Therefore, this study aims to determine the incidence of stunting and its determinant factors in children aged 12-59 months in Palopo city, South Sulawesi, Indonesia. This study used a case control design. The subjects of this study were mothers who have toddlers aged 12-59 months. sampling with purposive sampling. 200 samples were collected for analysis. Data analysis using odds ratios. The proportion of stunting among toddlers 12-59 months was higher in children under five with a history of normal birth weight $(70.8 \%)$ and under five who had no history of infection $(84.0 \%)$. Low family income for stunting toddlers $(78.0 \%)$. The results of statistical tests showed that LBW $(\mathrm{OR}=5.37)$, history of infection $(\mathrm{OR}=2.53)$ and family income $(\mathrm{OR}=6.30$ ) were determinants of stunting. This study shows that the determinants of stunting incidence in children aged 12-59 months are low birth weight, infectious diseases and low family income.
\end{abstract}

Keywords: Stunting, Toddler, LBW, Socio-Economy

\section{Introduction}

Child growth is one of the indicators of public health in monitoring the nutritional status and health of a community (Atsu et al., 2017). Stunting characterized by a z-score <-2SD $(\mathrm{TB} / \mathrm{U})$ is a global public health problem, affecting the potential for linear growth in children. It affects 165 million (26\%) children under 5 years of age worldwide (Black et al., 2013). Linear growth failure in children (stunting) is related to various consequences of health problems and is irreversible (Tariku et al., 2017). Indonesia is in the fifth rank of the highest prevalence of stunting in the world (Nutrition, 2013). Basic Health Research Report shows stunting under five in Indonesia reaches $30.8 \%$.

South Sulawesi Nutritional Status Monitoring (PSG) data in 2017, under five who experienced stunting were $34.8 \%$ (24.6\% short and $10.2 \%$ very short). The prevalence of stunting in the city of Palopo in 2018 was $36.0 \%$ (Basic, 2018). Stunting is closely related to indicators of nutritional status of children under five based on the TB/U (height / age) index, thus providing an indication of chronic chronic nutritional disorders (Rahmawati et al., 2018). The predictor of stunting in infants is LBW which will result in toddlers experiencing growth problems (Torlesse et al., 2016).

Stunting can be caused by internal factors such as infectious diseases and external factors. External factors for children under five include a history of exclusive breastfeeding, lack of access to nutritious food due to low family income. Socio-economic factors are factors that indirectly and fundamentally affect the occurrence of stunting in children under five (Rahmawati et al., 2018; Desa et al., 2017). Many factors influence the incidence of stunting in children under five, therefore it is very important to study the risk factors for stunting in childhood so that strategies can be designed to overcome this problem. Therefore, this study aimed to investigate stunting and its associated factors in toddlers aged 12-59 months. 


\section{Methods}

This research is a quantitative study with a case control design. The subjects of this study were mothers who have toddlers aged 12-59 months with stunting and normal nutritional status. Sampling was by purposive sampling. The number of respondents in this study were 200 mothers who had children aged 12-59 months. They were divided into 2 groups, namely the case group with 100 stunting infants and the control group with 100 normal children under five. The independent variables of this study were determinants of stunting, the dependent variable was birth weight, exclusive breastfeeding, history of infectious diseases (diarrhea and ARI), family socioeconomic level (number of children under five in the family, number of family members and family income). Data on the determinants of the incidence of stunting used questionnaires and anthropometric measurements for toddlers, including body weight and height. Data analysis used univariate, bivariate and multivariate analysis. Data were analyzed using odds ratio test.

\section{Results and Discussion}

A total of 200 respondents were collected in this research. Characteristics of children under five are male $48 \%$ and female $52 \%$. Toddler ages ranged from 12-35 months (77.5\%). The respondent's birth history was normal $(94.5 \%)$. A total of $89.0 \%$ of normal baby birth weight ( $\geq 2500$ grams). Toddlers do not have a history of infections such as diarrhea and ARI (47.5\%). Toddlers were given complementary feeding at $\geq 6$ months of age as much as $56.5 \%$. Most toddlers were given IMD at birth $(82.0 \%)$. Complete under five immunization status $(88.5 \%)$ (Table 1).

Table 1. Frequency Distribution of Toddler Characteristics

\begin{tabular}{|l|c|c|}
\hline \multicolumn{1}{|c|}{ Variable } & f & $\%$ \\
\hline Sex & & \\
Male & 96 & 48,0 \\
Female & 104 & 52,0 \\
\hline $\begin{array}{l}\text { Toddler age } \\
12-35\end{array}$ & 155 & 77,5 \\
$36-47$ & 36 & 18,0 \\
$38-59$ & 9 & 4,5 \\
\hline History of Birth of a Baby & 189 & 94,5 \\
$\quad$ Normal & 11 & 5,5 \\
$\quad$ Premature & & \\
\hline Baby Birth Weight & 178 & 89,0 \\
$\quad$ Normal & 22 & 11,0 \\
LBW & & \\
\hline History of Infection & 85 & 42,5 \\
$\quad \begin{array}{l}\text { Yes } \\
\text { No }\end{array}$ & 115 & 47,5 \\
\hline History of complementary & & \\
foods & & \\
$\quad \geq 6$ months & 113 & 56,5 \\
$<6$ months & 87 & 47,5 \\
\hline History of Early Initiation \\
of Breastfeeding & & \\
$\quad \begin{array}{l}\text { Yes } \\
\text { No }\end{array}$ & 164 & 82,0 \\
\hline
\end{tabular}




\begin{tabular}{|c|c|c|}
\hline Immunization Status & & \\
Complete & 177 & 88,5 \\
Not Complete & 23 & 11,5 \\
\hline Total & $\mathbf{2 0 0}$ & $\mathbf{1 0 0 , 0}$ \\
\hline
\end{tabular}

Table 2 illustrates that the mean age of mothers under five is $15-34$ years $(74.0 \%)$. The history of maternal ANC visits during pregnancy was 4 times (84.5\%). Mother under five with a height $\geq 150 \mathrm{~cm}$ as much as $96.5 \%$. The most occupations of fathers under five are others, namely TNI, farmers, honorary, daily laborers, fishermen $(32.0 \%)$, the work of mothers is housewives (81.0\%). Parents' education is SMA (47.0\%) and (56.5\%). The number of children under five in the family is 1 toddler $(70.5 \%)$ and the number of family members $<4$ people $(67.0 \%)$. Families of children under five have a low income, that is, under the UMP (<IDR $3,000,000)(57.0 \%)$.

Table 2. Characteristics of Families under Five

\begin{tabular}{|c|c|c|}
\hline Variable & $\mathbf{f}$ & $\%$ \\
\hline $\begin{array}{c}\text { Mother's Age } \\
15-34 \\
35-50 \\
\end{array}$ & $\begin{array}{c}148 \\
49 \\
\end{array}$ & $\begin{array}{l}74,0 \\
24,5\end{array}$ \\
\hline $\begin{array}{c}\text { ANC History } \\
4 \text { times } \\
\leq 3 \text { times }\end{array}$ & $\begin{array}{c}169 \\
31\end{array}$ & $\begin{array}{l}84,5 \\
15,5\end{array}$ \\
\hline $\begin{array}{l}\text { Mother's Height } \\
\text { High } \\
\text { Short } \\
\end{array}$ & $\begin{array}{c}193 \\
7 \\
\end{array}$ & $\begin{array}{c}96,5 \\
3,5\end{array}$ \\
\hline $\begin{array}{l}\text { Father's Work } \\
\text { Civil Servant } \\
\text { Private employees } \\
\text { BUMN } \\
\text { Entrepreneur } \\
\text { Others }\end{array}$ & $\begin{array}{c}5 \\
62 \\
2 \\
67 \\
64\end{array}$ & $\begin{array}{c}2,5 \\
31,0 \\
1,0 \\
33,5 \\
32,0\end{array}$ \\
\hline $\begin{array}{l}\text { Mother's work } \\
\text { Civil Servant } \\
\text { Private employees } \\
\text { Entrepreneur } \\
\text { House Wife } \\
\text { Others }\end{array}$ & $\begin{array}{c}7 \\
9 \\
13 \\
162 \\
9\end{array}$ & $\begin{array}{c}3,5 \\
4,5 \\
6,5 \\
81,0 \\
4,5\end{array}$ \\
\hline $\begin{array}{l}\text { Father's Education } \\
\text { No school } \\
\text { Primary school } \\
\text { Junior High } \\
\text { High school } \\
\text { D3 / Diploma } \\
\text { S1 / Bachelor }\end{array}$ & $\begin{array}{c}2 \\
19 \\
18 \\
94 \\
2 \\
65\end{array}$ & $\begin{array}{c}1,0 \\
9,5 \\
9,0 \\
47,0 \\
1,0 \\
32,5\end{array}$ \\
\hline
\end{tabular}




\begin{tabular}{|l|c|c|}
\hline Mother's Education & 3 & 1,5 \\
No school & 12 & 6,0 \\
Primary school & 25 & 12,5 \\
Junior High & 113 & 56,5 \\
High school & 8 & 4,0 \\
D3 / Diploma & 39 & 19,5 \\
S1 / Bachelor & & \\
\hline $\begin{array}{l}\text { Number of Toddlers in } \\
\text { the Family }\end{array}$ & 141 & 70,5 \\
1 & 59 & 29,5 \\
\hline 2-4 & & \\
\hline $\begin{array}{l}\text { Number of Family } \\
\text { Member }\end{array} 4$ & 66 & 33,0 \\
<4 & 134 & 67,0 \\
\hline Income Total & 86 & 43,0 \\
High & 114 & 57,0 \\
\hline Low & $\mathbf{2 0 0}$ & $\mathbf{1 0 0 , 0}$ \\
\hline
\end{tabular}

Table 3. Determinant Factors of Stunting Incidence in Toddlers (12-59 Months) in Palopo City

\begin{tabular}{|c|c|c|c|c|c|c|c|}
\hline \multirow{3}{*}{ Variable } & \multicolumn{4}{|c|}{ Nutritional Status } & \multirow{2}{*}{\multicolumn{2}{|c|}{ Total }} & \multirow[t]{3}{*}{ OR } \\
\hline & \multicolumn{2}{|c|}{ Stunting } & \multicolumn{2}{|c|}{ Not Stunting } & & & \\
\hline & $\mathrm{n}$ & $\%$ & $\mathrm{n}$ & $\%$ & $\mathrm{n}$ & $\%$ & \\
\hline $\begin{array}{l}\text { Birth Weight } \\
\text { Normal } \\
\text { LBW }\end{array}$ & $\begin{array}{l}82 \\
18\end{array}$ & $\begin{array}{l}70,8 \\
18,0\end{array}$ & $\begin{array}{c}96 \\
4\end{array}$ & $\begin{array}{c}95,4 \\
4,0\end{array}$ & $\begin{array}{c}178 \\
22\end{array}$ & $\begin{array}{l}89,0 \\
11,0\end{array}$ & $\begin{array}{c}5,27 \\
(1,71- \\
16,19)\end{array}$ \\
\hline $\begin{array}{l}\text { History of Infection } \\
\text { Yes } \\
\text { No }\end{array}$ & $\begin{array}{l}16 \\
84\end{array}$ & $\begin{array}{l}16,0 \\
84,0\end{array}$ & $\begin{array}{c}7 \\
93 \\
\end{array}$ & $\begin{array}{c}7,0 \\
93,0\end{array}$ & $\begin{array}{c}23 \\
177 \\
\end{array}$ & $\begin{array}{l}11,5 \\
88,5\end{array}$ & $\begin{array}{c}2,53 \\
(0,99-6,45)\end{array}$ \\
\hline $\begin{array}{l}\text { Number of } \\
\text { Toddlers } \\
1 \\
2-4\end{array}$ & $\begin{array}{l}66 \\
34 \\
\end{array}$ & $\begin{array}{l}66,0 \\
34,0\end{array}$ & $\begin{array}{l}75 \\
25\end{array}$ & $\begin{array}{l}75,0 \\
25,0\end{array}$ & $\begin{array}{c}141 \\
59\end{array}$ & $\begin{array}{l}70,5 \\
29,5\end{array}$ & $\begin{array}{c}0,65 \\
(0,35-1,19)\end{array}$ \\
\hline $\begin{array}{l}\text { Number of Family } \\
\text { Members } \\
\geq 4 \\
<4\end{array}$ & $\begin{array}{l}30 \\
70\end{array}$ & $\begin{array}{l}30,0 \\
70,0\end{array}$ & $\begin{array}{l}36 \\
64\end{array}$ & $\begin{array}{l}36,0 \\
64,0\end{array}$ & $\begin{array}{c}65 \\
134\end{array}$ & $\begin{array}{l}33,0 \\
67,0\end{array}$ & $\begin{array}{c}1,31 \\
(0,73-2,37)\end{array}$ \\
\hline $\begin{array}{l}\text { Family Income } \\
\text { High } \\
\text { Low }\end{array}$ & $\begin{array}{l}22 \\
78\end{array}$ & $\begin{array}{l}22,0 \\
78,0\end{array}$ & $\begin{array}{l}64 \\
36\end{array}$ & $\begin{array}{l}64,0 \\
36,0\end{array}$ & $\begin{array}{c}86 \\
114\end{array}$ & $\begin{array}{l}43,0 \\
57,0\end{array}$ & $\begin{array}{c}6,30 \\
(3,37- \\
11,78) \\
\end{array}$ \\
\hline Total & 100 & 100,0 & 100 & 100,0 & 200 & 100,0 & \\
\hline
\end{tabular}

The proportion of stunting among toddlers 12-59 months was higher in children under five with a history of normal birth weight $(70.8 \%)$ as well as in children under five with no history of infection (84.0\%). Socio-economy is one of the causes of stunting which is indicated by the number of children under five in a family of 2-4 people (34.0\%), the number of family members 
in one house $\geq 4(30.0 \%)$ people, and low family income $(78.0 \%)$ (Table 3$)$. The results of statistical tests in Table 3 show that LBW $(\mathrm{OR}=5.37)$, history of infection $(\mathrm{OR}=2.53)$ and family income $(\mathrm{OR}=6.30)$ are determinants of stunting.

Childhood stunting has lifelong consequences, not only related to health problems, but also related to poverty. This is due to chronic malnutrition that can occur due to hereditary cycles. Undernourished mothers tend to have children with malnutrition (Aguayo et al., 2016). Several studies from various countries show that various socio-demographic determinants are statistically proven to be associated with stunting. The following is a picture of the analysis of socio-demographic determinants related to stunting (World Health Organization, 2014). In this study, low birth weight had a 5.37 times greater risk of having a stunted toddler.

Infants with LBW experience disorders of the digestive tract that are not functioning properly, such as being unable to absorb fat and digest protein resulting in a lack of nutrient reserves in the body, resulting in impaired growth of LBW babies, if this situation continues accompanied by inadequate feeding will result in stunting (Nadiyah et al., 2014; Mustikaningrum et al., 2016). The analysis showed that a history of infectious diseases such as diarrhea and ARI had 2.53 times the risk of stunting. Infectious diseases are caused due to lack of nutritional intake, especially protein and babies are not given breast milk resulting in decreased immune system. Chronic infection can interfere with growth in children under five (Mustikaningrum et al., 2016).

Infection is one of the direct causes of malnutrition. In previous studies, infectious diseases such as diarrhea and pneumonia have been shown to have a significant relationship with the incidence of stunting in children under five (Reinbott et al., 2015). Low-income families have a 6.30 times greater risk of having children under five with stunting than families with high or moderate income. Stunting in children under five is caused by low family income factors. Low family income can lead to limited family purchasing power for food which has an impact on nutritionally vulnerable groups, namely toddlers (Rahayu et al., 2019). Toddler years require adequate nutrition for growth. Studies in Bangladesh show a correlation between poverty and stunting occurs in low-income families and a large number of siblings (Rahman et al., 2015).

\section{Conclusion}

Stunting is a public health problem in Indonesia, especially in the city of Palopo. This study shows that the determinants of stunting incidence in children aged 12-59 months are low birth weight, infectious diseases and low family income. It is necessary to identify the causes of stunting including family demographic factors to prevent stunting.

\section{Conflict of Interest}

The authors stated that there is no conflict of interest.

\section{Thank-You-Note}

Researchers would like to thank the Directorate General of Research and Development Strengthening of the Ministry of Research and Technology / Research and Innovation Agency of the Republic of Indonesia for providing research funds for the Beginner Lecturer Research scheme for the 2020 budget year.

\section{References}

Aguayo, V. M., Nair, R., Badgaiyan, N., \& Krishna, V. (2016). Determinants of stunting and poor linear growth in children under 2 years of age in India: An in-depth analysis of Maharashtra's comprehensive nutrition survey. Maternal \& child nutrition, 12, 121140. 
Atsu, B. K., Guure, C., \& Laar, A. K. (2017). Determinants of overweight with concurrent stunting among Ghanaian children. BMC pediatrics, 17(1), 177.

Black, R. E., Victora, C. G., Walker, S. P., Bhutta, Z. A., Christian, P., De Onis, M., ... \& Uauy, R. (2013). Maternal and child undernutrition and overweight in low-income and middle-income countries. The lancet, 382(9890), 427-451.

Dasar, R. (2018). Laporan Hasil Riset Kesehatan Dasar (Riskesdas) Nasional 2007. Jakarta: Badan Litbangkes, Depkes RI.

Desa, K., Tertinggal, P. D., \& Indonesia, T. R. (2017). Buku saku desa dalam penanganan stunting. Jakarta: Kementerian Desa, Pembangunan Daerah Tertinggal, dan Transmigrasi Republik Indonesia .

Mustikaningrum, A. C., Subagio, H. W., \& Margawati, A. (2016). Determinan kejadian stunting pada bayi usia 6 bulan di Kota Semarang. Jurnal Gizi Indonesia (The Indonesian Journal of Nutrition), 4(2), 82-88.

Nadiyah, N., Briawan, D., \& Martianto, D. (2014). Faktor Risiko Stunting Pada Anak Usia 023 Bulan Di Provinsi Bali, Jawa Barat, Dan Nusa Tenggara Timur. Jurnal gizi dan pangan, $9(2)$.

Rahayu, V. I., Susanto, N., \& Fitriani, A. (2019). Determinan kejadian stunting pada balita di Desa Wukirsari, Kecamatan Cangkringan, Sleman, Yogyakarta Determinant of stunting among children under five years old in Wukirsari Village, Cangkringan Subdistrict, Sleman, Yogyakarta.

Rahman, M. S., Mondal, M. N. I., Islam, M. R., Ahmed, K. M., Karim, M. R., \& Alam, M. S. (2015). Under weightiness among ever-married non-pregnant women in Bangladesh: a population based study. Univ J Food Nutr Sci, 3(2), 29-36.

Rahmawati, V. E., Pamungkasari, E. P., \& Murti, B. (2018). Determinants of stunting and child development in Jombang District. Journal of Maternal and Child Health, 3(1), 68-80.

Reinbott, A., Kuchenbecker, J., Herrmann, J., Jordan, I., Muehlhoff, E., Kevanna, O., \& Krawinkel, M. (2015). A child feeding index is superior to WHO IYCF indicators in explaining length-for-age Z-scores of young children in rural Cambodia. Paediatrics and international child health, 35(2), 124-134.

Tariku, A., Biks, G. A., Derso, T., Wassie, M. M., \& Abebe, S. M. (2017). Stunting and its determinant factors among children aged 6-59 months in Ethiopia. Italian journal of pediatrics, 43(1), 112.

Torlesse, H., Cronin, A. A., Sebayang, S. K., \& Nandy, R. (2016). Determinants of stunting in Indonesian children: evidence from a cross-sectional survey indicate a prominent role for the water, sanitation and hygiene sector in stunting reduction. BMC public health, $16(1), 669$.

World Health Organization. (2014). Childhood stunting: Challenges and opportunities. In Report of a colloquium. Geneva: World Health Organization. 